\title{
Ecological attributes of the benthic community and indices of water quality in urban, rural and preserved environments
}

\author{
Atributos ecológicos da comunidade bentônica e índices de qualidade \\ da água de ambientes urbanos, rurais e preservados \\ Claudia Eiko Yoshida and Ana Paula Pozzo Rios Rolla \\ Associação Mata Ciliar, Av. Emílio Antonon, 1000, Chácara Aeroporto, \\ CEP 13212-010, Jundiaí, SP, Brazil \\ e-mail: ceyoshida@uol.com.br
}

\begin{abstract}
Introduction: Reference streams are pristine streams, untouched or unaltered by man, it being possible to use their environmental characteristics as quality threshold values. Besides the organic impacts measured via water quality biological monitoring programs, it has become necessary to evaluate the relationship between alterations in the landscape of streams and surrounding areas and changes in the structure of the macroinvertebrate community; Aim: The objective of the present study was to correlate the changes in the landscape with the ecological attributes of the community and indices of water quality, and to recommend reference condition values for the integrity of streams in the region of Jundiai (SP); Methods: The benthic fauna were sampled in three urban streams, three rural streams and three preserved streams during July 2010, using a Surber-type sampler. The characteristics of the landscape were evaluated by means of Diversity of Habitat; the community, analyzed for several biodiversity indices, and; the water quality assessed using the indices River-BCI, BMWP-CETEC (CETEC - Science and Technology Center), ASPT and SOMI (SOMI - Serra dos Órgãos Multimetric Index (Serra dos Órgãos is a mountain range national park in the state of Rio de Janeiro)); Results: The structure and the composition of the communities varied according to the stream and this was reflected in the values of the biological and environmental quality indices. The best conditions were found in preserved streams, intermediate streams and rural streams while the worst conditions were found in the urban streams. The significant Pearson correlations $(r>0.73$ and $P<0.05)$ between the diversity of habitat index and the ecological and water quality index attributes in the streams of Jundiai demonstrated that diversity of habitat may be a good predictor of the environmental characteristics evaluated.
\end{abstract}

Keywords: environmental degradation, Atlantic Forest, habitat diversity.

Resumo: Introduçáo: Riachos de referência dizem respeito a ambientes íntegros, sendo possível utilizar suas características ambientais como valores patamares de qualidade. Além dos impactos orgânicos medidos pelos programas de biomonitoramento da qualidade da água, se faz necessário avaliar as relações entre as alterações da paisagem dos riachos e de seu entorno com as mudanças na estrutura da comunidade de macroinvertebrados desses ambientes; Objetivos: $\mathrm{O}$ presente estudo teve como objetivos correlacionar as mudanças da paisagem com os atributos ecológicos da comunidade e índices de qualidade da água e, recomendar valores de condição referencial de integridade de riachos para a regiáo de Jundiaí/SP; Métodos: Foram amostradas a fauna bentônica de três riachos urbanos, três rurais e três preservados, com amostrador do tipo Surber, em julho de 2010. As características da paisagem foram avaliadas por meio da Diversidade de Habitat (DH); a comunidade, analisada quanto a $S, N$, J', H' e curvas de rarefaçáo $S$ e de dominância $K$ e; a qualidade da água aferida pelos índices ICB Rio, BMWP-CETEC, ASPT e SOMI; Resultados: A estrutura e a composição das comunidades variaram em função dos riachos e refletiram-se nos valores dos índices biológicos e de qualidade ambiental. As melhores condiçóes foram encontradas nos riachos preservados, as intermediárias, nos riachos rurais e, as piores, nos urbanos. As significativas correlaçôes $(r>0.73$ e $\mathrm{P}<0.05)$ entre o índice de diversidade de habitat $(\mathrm{DH})$ e os atributos ecológicos e de qualidade da água dos riachos de Jundiaí, demonstraram que $\mathrm{DH}$ pode ser um bom preditor das características ambientais avaliadas e como tal, recomenda-se como valores de condição de referencia de riachos: $\mathrm{DH} \geq 80 ; \mathrm{H}^{\prime} \geq 2,3$ e J $\geq 0.8$ (família como nível taxonômico) e; qualidade de água boa (ICB Rio, BMWP-CETEC e BI), de levemente poluída a limpa (ASPT) e regular (SOMI).

Palavras-chave: degradação ambiental, Mata Atlântica, diversidade de habitat. 


\section{Introduction}

Reference streams relate to whole environments, in close to natural condition, though hard to find in most regions of the world (Baptista, 2007). Because of this difficulty, Bailey et al. (2004), define as a reference environment one which has an ecosystem that is considered to be "healthy" or "acceptable", with measureable environmental characteristics which permit comparison with impacted environments.

One of the ways used by some government agencies in Brazil to evaluate the impact on bodies of water, is the use of biological monitoring of the macroinvertebrate community. This tool enables the classification of water in rivers by means of indices of quality such as River-BCI - Benthic Community Index for Rivers (CETESB, 2009) (CETESB - São Paulo State Environment Agency) and the BMWPCETEC - Biological Monitoring Working Party Score System (Junqueira and Campos, 1998); both are estimated using the sensitivity and tolerance of taxa to the organic load in the system, common to urban areas. Although these indices are fine for evaluating organic waste, they do not consider diffuse impacts in the surrounding areas of the streams such as reduction in riparian woodlands, riverbank erosion, silting and the straightening of channels, damming caused by human activity. According to Roth et al. (1996) these are also factors of change in the structure of the aquatic community and therefore should be included in the evaluation of their environmental quality.

Studies conducted in recent years (Callisto et al., 2001; Paz et al., 2008), evidence the possibility of using the Habitat Diversity protocol devised by Callisto et al. (2002), to demonstrate the relationship between the levels of environmental degradation of the landscape and the change in the structure of the aquatic community in Brazil's streams. By mapping landscape to the characteristics of the benthic invertebrate fauna, Baptista et al. (2007) also proposed a multimetric index (SOMI) that represents ecological attributes, as do RiverBCI and BMWP-CETEC. However, it is based on a quality reference condition in an area of the Atlantic Forest, with the aim of evaluating the lotic environment under an assumption of ideal ecological quality that would be found in the absence of anthropic interference. To this end, Baptista et al. (2007) considered as whole streams those classified as excellent and very good according to the RCE protocol (Riparian, Channel and Environmental Inventory; Petersen, 1992), which has a similar proposition to the Habitat Diversity.
Both the RCE and the Habitat Diversity protocols are scored via visual evaluation, elements of the landscape and streams whose surrounding areas and channel aspects are the best preserved (larger expanse of riparian woodland, little or no erosion, meanders, presence of rapids etc.) receive the highest scores. However, a preliminary, comparative study between RCE and Habitat Diversity showed that the latter, as it did not include a weighting for the characteristics of the ichthyofauna, allowed a quicker evaluation of the environments and was more appropriate in the classification of urban streams.

Therefore, with the aim of contributing to the establishment of a standard procedure for the definition of reference areas in Brazil, the objective of the present study was to study the relationship between Habitat Diversity and the biological attributes of the benthic community in order to evaluate the environmental integrity and to recommend reference condition values for streams in the region of Jundiaí (São Paulo).

\section{Material and Methods}

The study was conducted in the city of Jundiaí (São Paulo) in nine streams: three urban streams, three rural streams, and three streams in an environmental protection area (Serra do Japi), defined according to soil occupation characteristics in the surrounding areas of the stream and their location within the city zoning (Supplementary Municipal Law no. 224/96) (Figures 1 and 2).

The collection of macroinvertebrates was conducted between July 9 and July 12, 2010, with a Surber-type sampler $(15 \times 15 \mathrm{~cm}$ and $500 \mu \mathrm{m}$ mesh $)$. The material collected was fixed in $70 \%$ alcohol for the subsequent screening, identification and counting of organisms under a stereo microscope. The identification of benthic organisms at the family level was based on Merrit and Cummins (1996), McCafferty (1998), Fernández and Dominguez (2001), Calor (2007) and Mugnai et al. (2010). The Chironomid larvae were identified in subfamilies and Annelida, Acari, Collembola, Nematoda and Turbellaria were identified in large groups.

In each stream, the goal was to mark out a segment of 100 meters, where six samples of benthic fauna were collected in an area of rapids and varied substrates (sand, gravel and leaf litter). The six samples were added together and the community was analyzed as to richness $(S$, number of taxa), abundance ( $\mathrm{N}$, number of individuals), index of equitability (J'), Shannon-Wiener index of diversity ( $\left.\mathrm{H}^{\prime}\right)$ and rarefaction curves for richness 
and dominance of taxa (Krebs, 1999 and Primer 6 software).

The evaluation of environmental integrity in the streams took place via the calculation of Habitat Diversity (Callisto et al., 2002) and biological monitoring of water quality using the following indices: Benthic Community Index for Rivers (River-BCI, CETESB, 2009), Biological Monitoring Work Party (BMWP-CETEC, Junqueira et al., 1998), Average Score per Taxa (ASPT, Chessman, 1995), Biotic Index (BI, Zimmerman, 1993) and the Serra dos Orgãos Multimetric Index (SOMI, Baptista et al., 2007). For the last mentioned index, the information required for the calculation of the percentage of fragmentary organisms was based on Merrit and Cummins (1996).

With the aim of testing statistical hypotheses $-\mathrm{H}_{0}$ : null correlation between the characteristics of environmental integrity through Habitat Diversity and ecological attributes of the community $(\mathrm{S}, \mathrm{H}$, J, River-BCI, BMWP-CETEC, ASPT, SOMI,

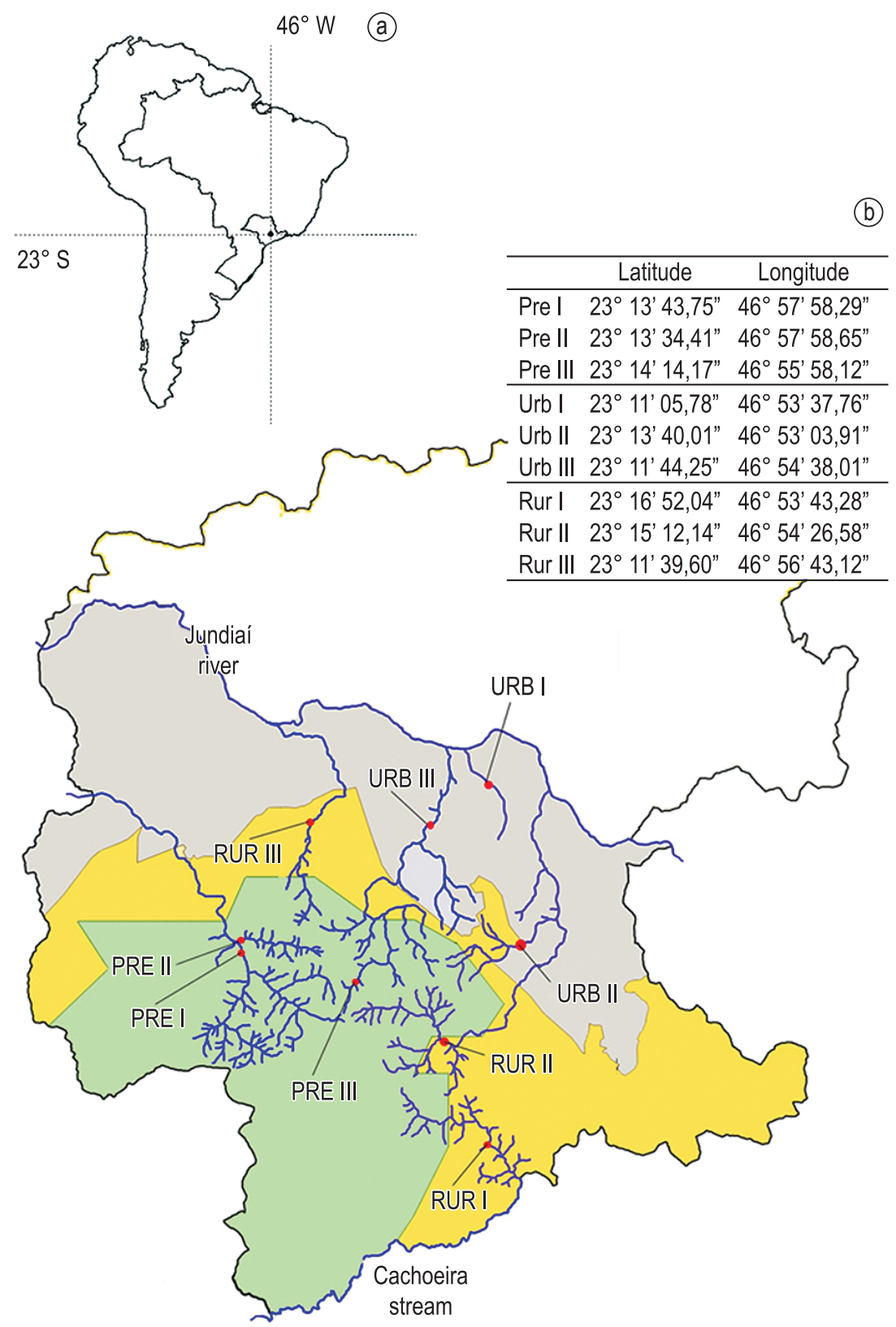

Figure 1. a) Location of Jundiaí in the state of São Paulo, Brazil. b) Boundary of Jundiaí City with the simplified hydric system of Jundiai River and Cachoeira Stream with the location of the sampled streams (red dots and table) in relation to the preserved area (green, PRE I, II and III), rural area (brown, RUR I, II and III) and urban area (gray, URB I, II and III). Map adapted from Planning and Environmental Secretary of Jundiaí. 

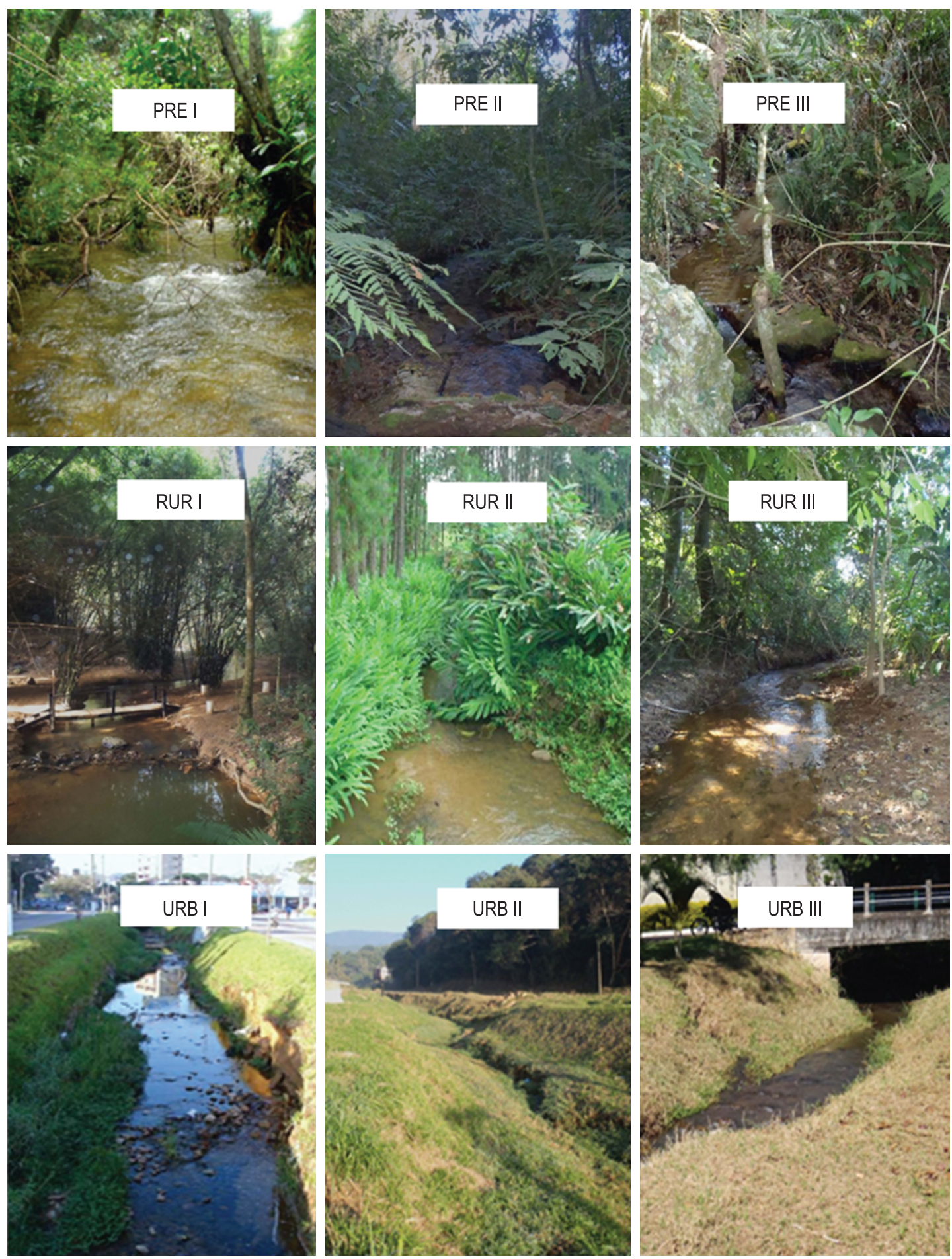

Figure 2. Margin occupation of sampled streams in preserved area (PRE I, II and III), rural area (RUR I, II and III) and urban area (URB I, II and III).

BI) and; $\mathrm{H}_{1}$ : existence of correlation between the characteristics of environmental integrity and ecological attributes of the community, the Habitat Diversity data were correlated with the ecological and water quality indices by means of the Pearson correlation (Statistica 7 software).

\section{Results}

In the streams studied, a total of 3,573 invertebrates were collected, distributed across 46 taxa belonging to Insecta, Annelida, Mollusca, Arthropoda Non-Insecta, Turbellaria and Nematoda. The structure and composition of the communities 
varied, depending on the streams, and were reflected in the values of the biological and environmental quality indices (Tables 1 and 2).

The richness rarefaction curve (Figure 3 ) and taxa dominance curve (Figure 4) showed that the most diverse and stable communities (low dominance and high equitability) were those observed in the streams in Rur III and in the preservation area (Pre I, Pre II and Pre III) and the opposite, lower diversity and stability, occurred in the rural streams RurI and RurII and in all the urban streams (Urb I, Urb II and Urb III).

Table 1. Taxa and abundance of benthic macroinvertebrates in urban streams (Urb I, II and III), rural streams (Rur I, II and III) and preserved streams (Pre I, II and III).

\begin{tabular}{|c|c|c|c|c|c|c|c|c|c|}
\hline & Urb I & Urb II & Urb III & Rur I & Rur II & Rur III & Pre I & Pre II & Pre III \\
\hline Acari & & 2 & & 5 & & & 1 & 3 & \\
\hline Aeshnidae & & & & 1 & & & & & \\
\hline Amphipoda & & & & & & & & 6 & \\
\hline Ancylidae & & 6 & & & 2 & 2 & & & \\
\hline Baetidae & & & 16 & 1 & 1 & & 22 & 3 & 1 \\
\hline Calamoceratidae & & & & & & 1 & & 1 & 3 \\
\hline Calopterygidae & & & & & & 1 & & 1 & \\
\hline Ceratopogonidae & & 1 & & 1 & & 4 & 2 & 2 & \\
\hline Chironominae & 426 & 14 & 7 & 367 & 7 & 35 & 23 & 27 & 1 \\
\hline Collembola & & 5 & & 4 & 5 & 1 & 1 & & 1 \\
\hline Corduliidae & & & & 1 & & & & & \\
\hline Dixidae & & & & & & & & 1 & \\
\hline Dryopidae & & 1 & & & & & & & \\
\hline Dugesiidae & & & & & 2 & 1 & 1 & 1 & \\
\hline Dytiscidae & & & & & & & 2 & & \\
\hline Elmidae & & & & 3 & 7 & 1 & 32 & 28 & 4 \\
\hline Empididae & & 3 & & 2 & 3 & 7 & 1 & 2 & \\
\hline Glossosomatidae & & & 1 & & & & 5 & & \\
\hline Gomphidae & & 1 & & 1 & & 2 & & & \\
\hline Gripopterygidae & & & & & & & 3 & 4 & 2 \\
\hline Hirudinea & 13 & & & & & & & & \\
\hline Hydrobiosidae & & & & & & & & & 2 \\
\hline Hydrophilidae & 3 & & & & & & & & \\
\hline Hydropsychidae & & & & 1 & 4 & 9 & 4 & 3 & 2 \\
\hline Hydroptilidae & & & 2 & 2 & & 2 & 1 & & \\
\hline Isopoda & & & & & 1 & & & & \\
\hline Leptoceridae & & & & & & & 14 & & \\
\hline Leptohyphidae & & & & & & & 3 & 17 & \\
\hline Leptophlebiidae & & & & & 1 & & 2 & 10 & \\
\hline Muscidae & & 2 & & & & & & & \\
\hline Nematoda & & 1 & 1 & & 11 & 1 & & 3 & 1 \\
\hline Oligochaeta & 1494 & 102 & 7 & 18 & 5 & 1 & 47 & 6 & 4 \\
\hline Orthocladinae & 199 & 20 & 41 & 25 & 16 & 7 & 15 & 32 & 12 \\
\hline Perlidae & & & & & & & 2 & 1 & \\
\hline Philopotamidae & & & & & & & & 1 & \\
\hline Physidae & 16 & & & & & & & & \\
\hline Planorbidae & & & & & & 1 & & & \\
\hline Psephenidae & & & & & & & & 2 & \\
\hline Pyralidae & & & & & & & & & 2 \\
\hline Simuliidae & & & 46 & 22 & 116 & 2 & 5 & 20 & 12 \\
\hline Sphaeridae & & & & 1 & 1 & & & & \\
\hline Stratiomyidae & & 1 & & & & & & & \\
\hline Tabanidae & & & & & & & & & 1 \\
\hline Tanypodinae & & 4 & 1 & 3 & 1 & 4 & 1 & & \\
\hline Tipulidae & & 1 & & 1 & & & & & \\
\hline Veliidae & & & & & & & & 2 & 1 \\
\hline Total & 2151 & 164 & 122 & 459 & 183 & 82 & 187 & 176 & 49 \\
\hline
\end{tabular}


Table 2. Calculated values for the ecological attributes of the benthic communities sampled in urban streams (Urb I, II and III), rural streams (Rur I, II and III) and preserved streams (Pre I, II and III) - richness (S), index of equitability (J'), Shannon-Wiener index of diversity $\left(\mathrm{H}^{\prime}\right)$ and calculated indices of environmental and biological quality - Habitat Diversity (HD), Benthic Community Index for Rivers (River-BCI), Biological Monitoring Work Party (BMWPCETEC), Average Score per Taxa (ASPT), Biotic Index (BI), Serra dos Órgãos Multimetric Index (SOMI).

\begin{tabular}{lccccccccc}
\hline & Urb I & Urb II & Urb III & Rur I & Rur II & Rur III & Pre I & Pre II & Pre III \\
\hline S & 6 & 15 & 9 & 18 & 16 & 18 & 21 & 23 & 15 \\
$\mathrm{~J}^{\prime}$ & 0.5 & 0.5 & 0.7 & 0.3 & 0.5 & 0.7 & 0.8 & 0.8 & 0.8 \\
$\mathrm{H}^{\prime}$ & 0.9 & 1.4 & 1.5 & 0.9 & 1.5 & 2.1 & 2.3 & 2.5 & 2.3 \\
HD & $41^{1}$ & $52^{\mathrm{I}}$ & $53^{\mathrm{I}}$ & $55^{\mathrm{A}}$ & $67^{\mathrm{A}}$ & $77^{\mathrm{A}}$ & $98^{\mathrm{N}}$ & $97^{\mathrm{N}}$ & $100^{\mathrm{N}}$ \\
River-BCI & $3.75^{\mathrm{B}}$ & $3.35^{\mathrm{R}}$ & $2.25^{\mathrm{G}}$ & $2.33^{\mathrm{G}}$ & $1.75^{\mathrm{G}}$ & $1.67^{\mathrm{G}}$ & $1.5^{\mathrm{G}}$ & $1.5^{\mathrm{G}}$ & $1.75^{\mathrm{G}}$ \\
BMWP-CETEC & $11^{\mathrm{T}}$ & $29^{\mathrm{B}}$ & $27^{\mathrm{B}}$ & $60^{\mathrm{R}}$ & $52^{\mathrm{R}}$ & $61^{\mathrm{G}}$ & $98^{\mathrm{G}}$ & $110^{\mathrm{G}}$ & $59^{\mathrm{R}}$ \\
ASPT & $2.75^{\mathrm{SP}}$ & $3.63^{\mathrm{SP}}$ & $4.5^{\mathrm{P}}$ & $4.62^{\mathrm{P}}$ & $4.73^{\mathrm{P}}$ & $4.69^{\mathrm{P}}$ & $5.76^{\mathrm{LP}}$ & $6.11^{\mathrm{C}}$ & $5.36^{\mathrm{LP}}$ \\
SOMI & $10^{\text {Po }}$ & $10^{\mathrm{Po}}$ & $8^{\mathrm{Po}}$ & $10^{\text {Po }}$ & $8^{\text {Po }}$ & $14^{\mathrm{R}}$ & $18^{\mathrm{R}}$ & $18^{\mathrm{R}}$ & $16^{\mathrm{R}}$ \\
BI & $7.12^{\text {FPo }}$ & $6.24^{\mathrm{M}}$ & $5.78^{\mathrm{M}}$ & $7.49^{\text {FPo }}$ & $5.32^{\mathrm{G}}$ & $6.09^{\mathrm{M}}$ & $5.17^{\mathrm{G}}$ & $4.6^{\mathrm{G}}$ & $4.61^{\mathrm{G}}$ \\
\hline
\end{tabular}

Classification of environmental quality according to the calculated indices: ${ }^{\mathrm{I}}$ Impacted, ${ }^{\mathrm{A}}$ Altered, ${ }^{\mathrm{N}} \mathrm{Natural,}{ }^{\mathrm{B}} \mathrm{Bad}$, ${ }^{\text {R}}$ Regular, ${ }^{\mathrm{G}}$ Good, ${ }^{\mathrm{T}}$ Terrible, ${ }^{\text {SP }}$ Severely Polluted, ${ }^{\text {P Polluted, }}{ }^{\text {LP}}$ Slightly Polluted, ${ }^{\mathrm{C}}$ Clean, ${ }^{\text {Po }}$ Poor, ${ }^{\mathrm{M}}$ Medium, ${ }^{\text {FPo }}$ Fairly Poor.

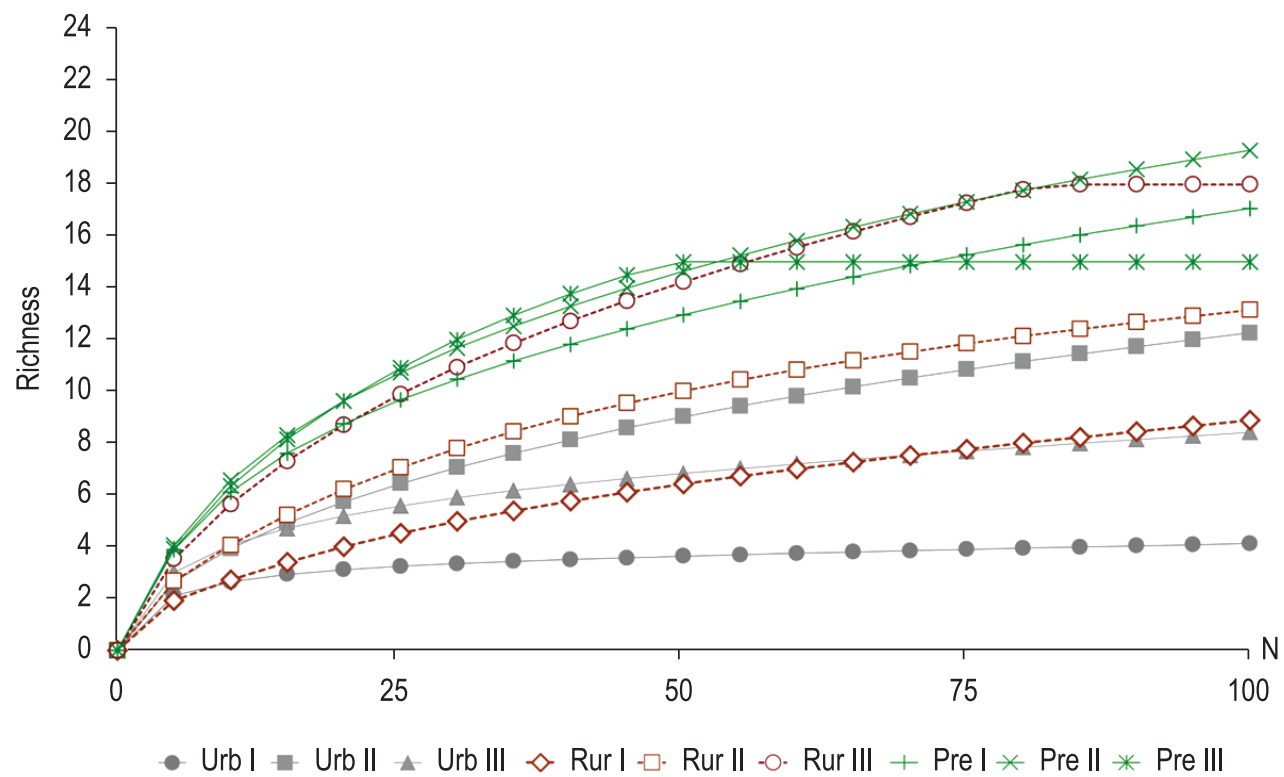

Figure 3. Rarefaction curve for richness of taxa in urban streams (Urb I, II and III), rural streams (Rur I, II and III) and preserved streams (Pre I, II and III).

The studied streams presented different quality levels depending on the calculation index (Table 2) and overall the best conditions were found in the preserved streams, followed by rural streams, while the worst were found in urban streams.

By comparing the indices of environmental and biological integrity (Table 2), it was found that the River-BCI was the one that diverged most in the classification of the streams - qualifying the conditions of the creeks Urb II, Urb III, Rur I, Rur II as normal and good, whereas the majority of the indices classified them as impacted, altered, bad, severely polluted or poor.
By combining the information on biological attributes and water quality indices, the SOMI classified preserved streams as normal with high diversity values (Pre I and Pre II). Moreover, within this context, conflicting classifications were noted for BMWP in Pre III (normal) and BI which showed better conditions in Rur II than in Rur III, the latter having higher ecological indices than those of the former.

In the Pearson correlation analysis (Table 3), with the exception of values for abundance $(\mathrm{N})$, it was found that Habitat Diversity values correlated with ecological and water quality indices $(r>0.73$ 


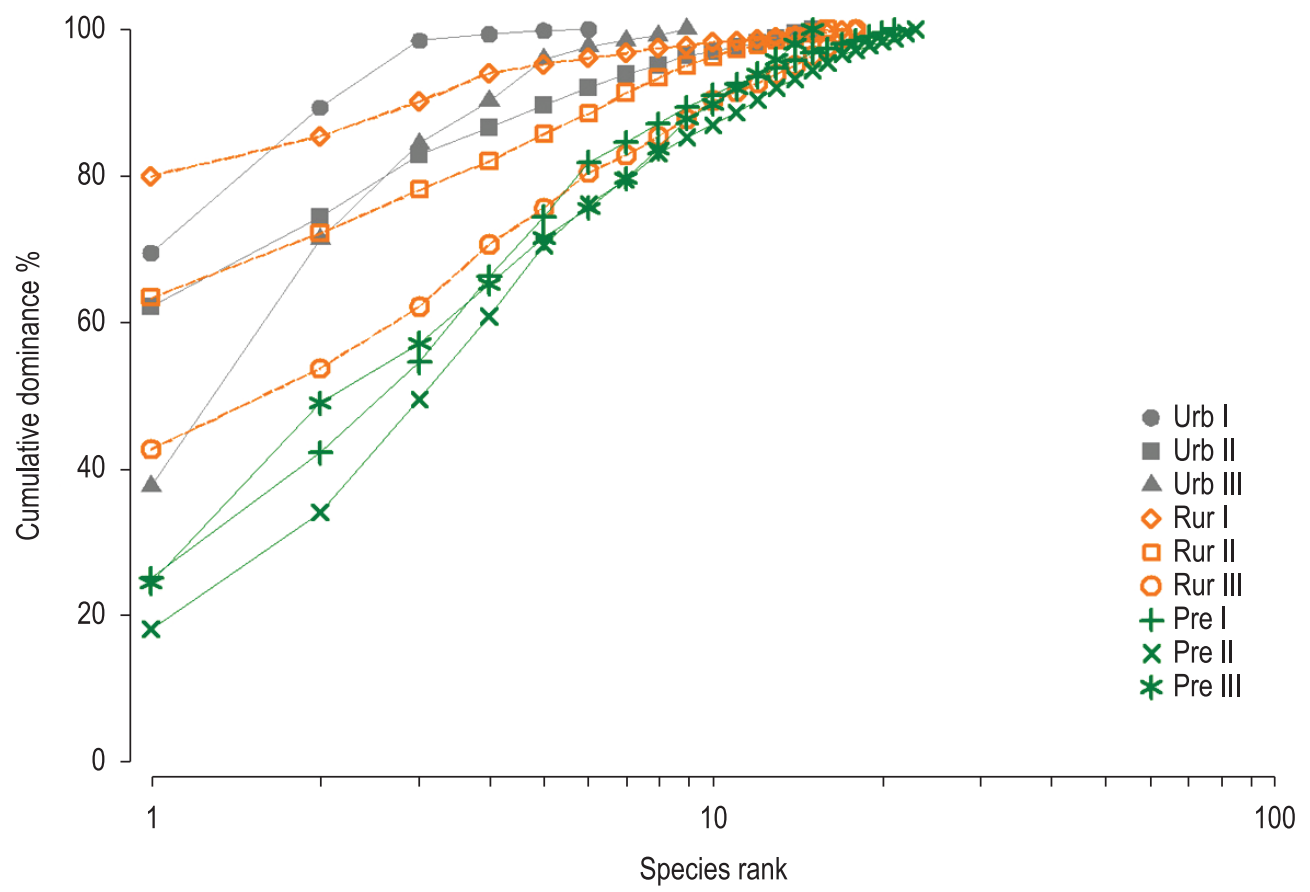

Figure 4. Dominance curve for taxa in urban streams (Urb I, II and III), rural streams (Rur I, II and III) and preserved streams (Pre I, II and III).

Table 3. Values for Pearson $r$ and $P$ obtained from Habitat Diversity (HD) multiple regression analysis versus richness $(\mathrm{S})$, index of equitability (J'), Shannon-Wiener index of diversity (H'), Benthic Community Index for Rivers (River$\mathrm{BCI}$ ), Biological Monitoring Work Party (BMWP-CETEC), Average Score per Taxa (ASPT), Biotic Index (BI), Serra dos Órgãos Multimetric Index (SOMI).

\begin{tabular}{lllllccccc}
\hline & BMWP-CETEC & ASPT & SOMI & River-BCI & BI & S & N & J' & H' $^{\prime}$ \\
\hline HD & 0.85 & 0.89 & 0.89 & -0.82 & -0.83 & 0.73 & -0.55 & 0.80 & 0.93 \\
$P$ & 0.004 & 0.001 & 0.001 & 0.007 & 0.006 & 0.026 & 0.125 & 0.010 & 0.000 \\
\hline
\end{tabular}

and $P<0.05)$, indicating that the increase in Habitat Diversity was associated with the increase in the values for BMWP, ASPT, SOMI, S, J' and H' and a reduction in the River-BCI and $\mathrm{BI}$.

\section{Discussion}

The results of loss in environmental quality of the urban and rural streams in Jundiai came within the expected responses listed by Suriano et al. (2010) - reduction in richness and Shannon-Wiener diversity; reduction in the abundance of Coleoptera, Ephemeroptera, Plecoptera and Trichoptera and an increase in the abundance of Diptera and Chironomidae.

The biological indices for the benthic community showed distinct classifications, however when considering just one index (River-BCI or BMWPCETEC or ASPT or SOMI or BI), the classification of water quality in general was consistent with the level of degradation - the worst conditions were seen in urban streams (Urb); intermediate conditions in the rural steams (Rur) and the best conditions in streams in the preservation area (Pre). The apparent incongruence in the environmental characterization of Pre III, classified as normal condition using the BMWP, was likely related to the lower richness found in low order $\left(1^{\text {st }}\right)$ streams (Vannote et al., 1980). The BI quality of Rur II (good) and Rur III (medium) reflected the differences in abundance ( $\mathrm{N}$ in Rur II $>\mathrm{N}$ in Rur III), which classified the streams inversely. Considering the fact that abundance is a measurement which can increase or decrease with the degradation of the environment (Rosenberg and Resh, 1993), it is recommended that the ecological attributes of the community should be analyzed in order to confirm the quality assessed by those indices using abundance values in their calculation (Zimmerman, 1993). Therefore, by weighting the information of Shannon-Wiener diversity, J equitability and the taxa rarefaction and 
dominance curves, Rur III would be classified as good and Rur II as medium.

The River-BCI, composed of weighting, richness, Shannon-Wiener diversity, the presence of organisms that are sensitive to pollution (Ephemeroptera, Plecoptera and Trichoptera) and dominance taxa ratios (Annelida and Chironomidae) (CETESB, 2009), overestimated values in environments of low diversity and underestimated values in environments of high diversity - classifying the urban streams appropriately, but with conditions in rural environments being equated to those in preserved environments.

The classification of stream quality, using the SOMI for the preserved streams of the city of Jundiai, suggests that the reference environments used in the Serra dos Órgãos (Baptista, 2007) may be richer and more diverse than those found in the Serra do Japi, which may have been down to the environmental degradation suffered throughout the history of the economic exploitation of the region (Jesus and Cavalheiro, 2004) as well as the biogeography of the taxa collected (Brown and Lomolino, 2006).

The significant correlations between the index of diversity of habitat and the biological and water quality attributes of the streams in the city of Jundiai, showed that Habitat Diversity may be a good predictor of the ecological attributes of the benthological community and water quality indices.

\section{References}

BAPTISTA, DF., BUSS, DF., EGLER, M., GIOVANELLI, A., SILVEIRA, MP. and NESSIMIAN, JL. 2007. A multimetric index based on benthic macroinvertebrates for evaluation of Atlantic Forest streams in Rio de Janeiro State, Brazil. Hydrobiologia, vol. 575, p. 83-94. http://dx.doi. org/10.1007/s10750-006-0286-x

BAILEY, R., NORRIS, RH. and REYNOLDSON, TB. 2004. Bioassessment of Freshwater Ecosystems: Using the Reference Condition Approach. Dordrecht: Kluwer Academic Publishers. 170 p. http://dx.doi. org/10.1007/978-1-4419-8885-0_7

BROWN, JH. and LOMOLINO, MV. 2006. Biogeografia. 2nd ed. Ribeirão Pretol: Ed FUNPEC. 691 p.

CALlisto, M., MORENO, P. and BARBOSA, FAR. 2001. Habitat Diversity and Benthic Functional Trophic Groups at Serra do Cipó, Southeast Brazil. Revista Brasileira de Biologia, vol. 61, no. 2, p. 259-266. http://dx.doi.org/10.1590/S003471082001000200008
CALLISTO, M., FERREIRA, WR., MORENO, P., GOUlART, M. and PETRUCIO, M. 2002. Aplicação de um protocolo de avaliação rápida da diversidade de habitats em atividades de ensino e pesquisa (MG-RJ). Acta Limnologica Brasiliensia, vol. 14, no. 1, p. 91-98.

CALOR, AR. 2007. Trichoptera. In Guia on-line de Identificação de larvas de Insetos Aquáticos do Estado de São Paulo. Available from: <http://sites.ffclrp.usp. br/aguadoce/index_trico $>$.

CHESSMAN, BC. 1995. Rapid assessment of rivers using macroinvertebrates: a procedure based on habitatspecific sampling, family level identification and biotic index. Australian Journal of Ecology, vol. 20, p. 122129. http://dx.doi.org/10.1111/j.1442-9993.1995. tb00526.x

Companhia Ambiental do Estado de São Paulo - CETESB. 2009. Qualidade das Águas Interiores no Estado de São Paulo. Departamento do Meio Ambiente do Estado de São Paulo. Série Relatórios - Anexo III.

ROTH, NE., ALLAN, JD. and ERICKSON, DL. 1996. Landscape influences on stream biotic integrity assessed at multiple spatial scales. Landscape Ecology, vol. 11, no. 3, p. 141-156. http://dx.doi. org/10.1007\%2FBF02447513

FERNÁNDEZ, HR. and DOMINGUEZ, E., eds. 2001. Guía para la determinación de los artrópodos bentónicos sudamericanos. Universidade Nacional de Tucumán; Faculdade de Ciencias Naturales; Instituto M. Lillo. 280 p.

JESUS, N. and CAVALHEIRO, F. 2004. Aspectos antrópicos, legais e conservacionistas na Serra do Japi, SP. In SANTOS, JE., CAVALHEIRO, F., PIRES, JSR., OLIVEIRA, CH. and PIRES, AMZCR., orgs. Faces da Polissemia da Paisagem: Ecologia, Planejamento e Percepção. São Carlos: Rima Editora. vol. 2, p. 805-821.

JUNQUEIRA, VM. and CAMPOS, SCM. 1998. Adaptation of the "BMWP" method for water quality evaluation in the Rio das Velhas watershed (Minas Gerais, Brazil). Acta Limnologica Brasiliensia, vol. 10, no. 2, p. 125-135.

KREBS, CJ. 1999. Ecological methodology. 2nd ed. Addison Wesley Longman. 581 p.

McCAFFERTY, WP. 1998. Aquatic Entomology: The Fishermen's and Ecologists' Illustrated Guide to Insects and Their Relatives. Jones and Bartlett Publishers. 448 p.

MERRIT, RW. and CUMMINS, KW., eds. 1996. An introduction to the aquatic insects of North America. Dubuque: Kendall; Hunt Publishing Company. $722 \mathrm{p}$.

MUGNAI, R., NESSIMIAN, JL. and BAPTISTA, DF. 2010. Manual de Identificação de Macroinvertebrados Aquáticos do Estado do Rio de Janeiro. Rio de Janeiro: Technical Books Editora. 174 p. 
PAZ, A., MORENO, P., ROCHA, L. and CALLISTO, M. 2008. Efetividade de áreas protegidas na conservação da qualidade das águas e biodiversidade aquática em sub-bacias de referência no rio das Velhas (MG). Neotropical Biology and Conservation, vol. 3, no. 3, p. 149-158. http://dx.doi. org/10.4013/nbc.20083.06

PETERSEN, R. 1992. The RCE: a riparian, channel and environmental inventory for small streams in the agriculture landscape. Freshwater Biology, vol. 27, p. 295-306. http://dx.doi. org/10.1111/j.1365-2427.1992.tb00541.x

ROSENBERG, DM. and RESH, VH. 1993. Freshwater Biomonitoring and Benthic Macroinvertebrates. New York: Chapman and Hall. 459 p.
SURIANO, MT., GESSNER, AAF., ROQUE, FO. and FROEHLICH, CG. 2010. Choice macroinvertebrate metrics to evaluate stream conditions in Atlantic Forest, Brazil. Environmental Monitoring Assessment, vol. 175, no. 1-4. p. 87-101.

VANNOTE, RI., MINSHALL, GW., CUMMINS, KW. SEDELL, JR. and CUSHING, CE. 1980. The River Continuum Concept. Canadian Journal of Fisheries and Aquatic Science, vol. 37, p. 130-137. http:// dx.doi.org/10.1139/f80-017

ZIMMERMAN, MC. 1993. The use of Biotic Index as an indication of water quality. In GOLDMAN, CA., HAUTA, PL., O'DONNELL, MA., ANDREWS, SE. and HEIDEN, R. van der., eds. Tested studies for laboratory teaching. Association for Biology Laboratory Education - ABLE. vol. 5, p. 85-98.

Received: 10 November 2010 Accepted: 09 October 2012 